Asian-Australasian Journal of

Food Safety and Security

ISSN 2523-1073 (Print) 2523-2983(Online)

www.ebupress.com/journal/aajfss

\title{
Article \\ Adequacy, utilization and repayment of society for social service credit on poor women of Mymensingh district in Bangladesh
}

\author{
Ashraful Alam Fakir ${ }^{1}$, Syful Islam², Md. Shofiqul Islam ${ }^{3}$, Md. Ashraful Hoque ${ }^{4}$ and Nowrin Islam Toma ${ }^{5}$ \\ ${ }^{1}$ Department of Agricultural Economics, Bangladesh Agricultural University (BAU), Mymensingh, Bangladesh \\ ${ }^{2}$ Agricultural Economics Division, Bangladesh Institute of Nuclear Agriculture (BINA), Mymensingh, \\ Bangladesh \\ ${ }^{3}$ Agricultural Economics Division, Bangladesh Sugarcrop Research Institute (BSRI), Ishwardi, Pabna, \\ Bangladesh \\ ${ }^{4}$ Department of Agricultural Finance, Bangladesh Agricultural University (BAU), Mymensingh, Bangladesh \\ ${ }^{5}$ Department of Agricultural Economics, Bangladesh Agricultural University (BAU), Mymensingh, Bangladesh
}

*Corresponding author: Syful Islam, Agricultural Economics Division, Bangladesh Institute of Nuclear Agriculture (BINA), Mymensingh, Bangladesh. E-mail: bausyful07@gmail.com

Received: 20 January 2021/Accepted: 29 April 2021/ Published: 31 May 2021

\begin{abstract}
The present study was an attempt to assess adequacy, utilization and repayment of Society for Social Service (SSS) credit on women beneficiaries. Interviewing 90 respondents randomly selected from five villages of Gouripur upazila of Mymensingh district in Bangladesh. The study revealed that both annual income and expenditure of the respondent households have increased after joining the micro credit program of SSS. Average annual income of agriculture and petty business enterprises are Tk. 80726.57 and 74864.14 respectively while average annual expenditure of agriculture and petty business enterprises are Tk. 78776.65 and 67912.37 respectively. Overall annual savings of agriculture and petty business enterprises are Tk. 3733.25 and 8475.09 respectively. Moreover, the women are better at present in respect of social awareness, freedom of attitude, financial freedom and also exercising their right in decision making activities. The study identified some crucial problems such as lack of adequate credit, high rate of interest, burden of old debt, lack of storage and marketing facilities, lack of improved seeds/breed and low price of their products, etc. The findings suggest that the amount of credit should be provided in accordance with their requirement, reduced interest rate and arranging for reasonable price of their products. Finally it was concluded that the SSS credit program benefited the women beneficiaries in respect of increasing income, creating self-employment opportunity, improving social status and at least in reducing the poverty from the study area.
\end{abstract}

Keywords: adequacy; socio-economic; utilization; repayment; household

\section{Introduction}

Bangladesh is one of the most densely populated countries of the world with a population of 159.9 million. Its density of population is 1215 persons per sq. $\mathrm{km}$. which is one of the highest in the world. The current population growth rate is 1.05 percent per annum (BBS, 2016). The incidence of poverty in Bangladesh is alarming. Among the 177 countries of the world, the position of Bangladesh is 142 in terms of Human Development Index (UNFPA, 2016). The recent estimate of the head count ratio is 23 percent for Pakistan, 27 percent for Sri Lanka and 35 percent for India. According to most of the usual indices of quality of life and of economic development, women in Bangladesh are disadvantaged in comparison to men. Traditional attitudes and customs in Bangladesh are the major obstacles to improve the situation of women. Bangladesh is an agrobased poor country and her economy is primarily dependent on agriculture. About 70 percent of its total population live in rural areas and are directly or indirectly engaged in wide range of agricultural activities $(\mathrm{MoF}$, 
2016). Micro credit could have by now reached over 60 percent of all poor households of the country and 37 percent of all households (World Bank, 2016). Now a day, there are a lot of national, international as well as local NGOs have been dealing with micro credit program in Bangladesh. Rural women are to a greater extent benefited by the micro credit program in our country. It has been improving rural livelihood and social empowerment of women in the country. Effects of micro credit program on rural women are also supposed to reduce poverty from the rural area.

SSS (Society for Social Service) a reputed national NGO has been working in Bangladesh since November, 1986 to help the rural distressed people. To alleviate poverty, it has launched a comprehensive program including self-employment, education for empowerment, income generation, etc. SSS believes that economic empowerment is the vital factor of development along with other factors like social, political and cultural aspects. Therefore, improvement of economic conditions has been considered to be the key factor in solving other problems through increased income. With this end in view, SSS initiated credit services program from the middle of 1991.The mission of SSS is to reduce poverty and to improve rural livelihood through provision of micro finance services in an innovative and sustainable way. With this philosophy, SSS has been specialized in providing credit for income generation of the landless poor where savings mobilization is a part of the credit program.

In Bangladesh, 49.56 percent (BBS, 2016) of the population are female and the role of women is strongly affected by social and religious barriers such as the veiling of women in public and the segregation of male and female. This restriction constraints women's participation work in outside home. However, productive involvement is high, especially in rural areas, which is not clearly reflected on official statistics. The main constraints related to the development of women members are illiteracy, lack of technical skill, social and cultural barriers, inadequate and ineffective training and so on. SSS mostly deals with landless women who are the disregarded class of people in the society. The women, the most vulnerable class constitutes the main target group of SSS activities and their participation is very important for the success of any development program in Bangladesh. This study would also provide information to the government policy planners and independent researchers for setting priorities to the alternative program strengthening evaluation mechanism and formation of effective rural development policies. The specific objectives were as: i. to assess the socio-economic characteristics of SSS beneficiaries in the study area; ii. to determine the adequacy of SSS credit, its utilization and repayment by the respondents; and iii. to identify the constraints faced by the beneficiaries.

\section{Materials and Methods}

Methodology plays an important role and enables the researcher to collect valid and reliable data and to use the information properly in order to arrive at correct conclusions. This chapter deals with the methodology of the present study which is described below.

\subsection{Selection of the study area}

Farm management research requires selection of an area where the research was to be conducted and related information requires to be collected. Moreover, the area in which farm business survey is to be conducted depends on the specific purpose of the survey and the possible co-operation from the respondents. Keeping this in mind five villages namely Kalipur, Kashier char, Sarker para, Shantibag and Shamvugonj under Gouripur upazila of Mymensingh district were randomly selected for the present study. The main reasons for selecting the villages were; (i) poverty reduction and women development program of SSS were in operation in these areas and SSS officials were more or less known to the researcher; (ii) credit receivers were available in the study area; (iii) the selected area is well served by roads and rickshaw services; and (iv) perfect cooperation with the respondents so that reliable data might be obtained.

\subsection{Period of survey}

For present study, data were collected by the researcher himself through personal interviews with the selected women. The period covered in present study was January to December, 2016. Data were collected during the months of August to September, 2017.

\subsection{Selection of the sample}

In a complete enumeration required information are collected from each and every element of the population making the survey very costly and time consuming. The present study is based on a sample survey of households which could represent reasonably a true picture of the entire population. After selection of the study area, a list of current beneficiaries was collected from the SSS branch office at Gouripur upazila of Mymensingh 
district in Bangladesh. From the list, 90 respondents were randomly selected out of 235 beneficiaries. Their IGAs were mainly confined to agriculture and petty business.

\subsection{Preparation of survey schedule}

In order to prepare final survey schedule for data collection a draft schedule was prepared keeping the objectives in view. The draft schedule was pretested in the study area. In the light of the experience gathered during pretesting necessary correction, modification and adjustment were made in the draft schedule. The final schedule was then cyclostyled and used for collecting data for the study.

\subsection{Methods of data collection}

Collection of reasonably reliable data from the field is not an easy task. It must be done properly since reliable data are the key to social science research and the success of a research work depends on the reliability of data to a greater extent. Dillon and Hardaker (1993) have suggested three main techniques by which farm survey data can be gathered: (i) direct observation, (ii) interviewing respondents and (iii) reviewing records kept by respondents. Keeping this in mind, direct interview method was followed to collect data from the respondents to whom the researcher would ask questions and recorded the answers very carefully.

\subsection{Processing and analysis of data}

Data were carefully analyzed with a view to achieving the objectives of the study. The collected data were first transferred to master sheets and compiled to facilitate the needed tabulation. The data which were recorded in local units were converted into standard units. Tabular technique was applied for the analysis of data using simple statistical tools like average, percentage, etc.

\subsection{Problems faced in data collection}

During the period of data collection, the researcher had to face some problems, which were: (i) most of the respondents initially hesitated to answer the question, as they thought that the investigator might use the information against their interest; (ii) due to lower education level, the respondents were initially unable to understand the questions asked by the researcher and in some cases irrelevant answers were given; (iii) sometimes it was not possible to collect data though the women were available at home. Because at that time they were busy with their household activities. So it is needed more than one visit to administer a single interview; (iv) most of the respondents did not keep proper written records and accounts of -their household activities; (v) due to lack of proper knowledge the respondents were indifferent to the objectives of the study and answered the questions in careless manner. However, repeated attempts were made to collect the correct information as far as possible.

In spite of all the difficulties pointed out above it is hoped that the study could fulfill to its objectives by constant persuasion and untiring patience of the researcher that would help for future research and for formulation of policy implications.

\section{Results and Discussion}

\subsection{Socio-economic characteristics of the beneficiaries}

This section has been made to identify the main socio-economic characteristics of the selected beneficiaries in the study area because of the fact that the receipt and utilization of credit might have been influenced by the socio-economic characteristics of the credit receivers (Alam, 2005). To investigate into the impact of SSS micro credit program, some important as well as relevant socio-economic characteristics of the beneficiaries are taken in to consideration.

\subsubsection{Family size and composition}

In this study, a family has been defined as a unit in which a number of people lives together and take meal from the same kitchen under the administration of one head. If any person of a family is employed outside but takes meals from the same kitchen while at home and shares the income and expenditure of the family, she/he has been considered to be a member of that family. Persons who have been employed in a family for household works like servants, day laborers, etc. are excluded in this definition. It is evident in Table 1 that the overall average family size was found to be 4.45 being almost similar to national average of 4.9 (BBS, 2016) which was 4.69 for agriculture group and 4.21 for petty business group. It is apparent from same table that most of the beneficiaries were in the age group of 15 to 57 years i.e. active age group while minimum was found in above 57 years of age during the study period (ASB, 2014). 
Table 1. Family composition of the respondent households (no.).

\begin{tabular}{lccccccc}
\hline \multirow{2}{*}{ Enterprise } & \multicolumn{2}{c}{ Below 15 years } & \multicolumn{1}{c}{$\mathbf{1 5 - 5 7}$ years } & \multicolumn{2}{c}{ Above 57 years } & \multirow{2}{*}{ Average family size } \\
\cline { 2 - 6 } & Male & Female & Male & Female & Male & Female & \\
\hline Agriculture & 0.69 & 0.74 & 1.56 & 1.66 & 0.04 & - & 4.69 \\
Petty business & 0.65 & 0.66 & 1.36 & 1.40 & 0.06 & 0.08 & 4.21 \\
All & 0.67 & 0.70 & 1.46 & 1.53 & 0.05 & 0.04 & 4.45 \\
\hline
\end{tabular}

Source: Field Survey, 2017

In the case of below 15 years age the male and female members constituted 14.75 and 16.67 percent for agriculture and they were 15.21 and 16.76 percent for petty business enterprise respectively. Similarly when adult respondents are considered, the percentages became 34.10 and 35.48 percent for agriculture, 33.70 and 35.33 percent for the petty business respectively (Table 2). Thus, there was little difference in the sex composition of family members of the respondent households under different categories (Khatun, 2009). The average family size of agriculture group was higher than that of business group during the period of study.

Table 2. Distribution of family members according to gender.

\begin{tabular}{|c|c|c|c|c|c|c|c|c|c|c|}
\hline \multirow[t]{3}{*}{ Enterprise } & \multicolumn{4}{|c|}{ Male } & \multicolumn{4}{|c|}{$\begin{array}{r}\text { Female } \\
\end{array}$} & \multirow{2}{*}{\multicolumn{2}{|c|}{ Total }} \\
\hline & \multicolumn{2}{|c|}{ Below 15 years } & \multicolumn{2}{|c|}{ Adult } & \multicolumn{2}{|c|}{ Below 15 years } & \multicolumn{2}{|c|}{ Adult } & & \\
\hline & No. & Percent & No. & Percent & No. & Percent & No. & Percent & No. & Percent \\
\hline Agriculture & 32 & 14.75 & 74 & 34.10 & 34 & 16.67 & 77 & 35.48 & 217 & 100 \\
\hline Petty business & 28 & 15.21 & 62 & 33.70 & 29 & 16.76 & 65 & 35.33 & 184 & 100 \\
\hline All & 60 & 14.96 & 136 & 33.91 & 63 & 16.71 & 142 & 34.42 & 401 & 100 \\
\hline
\end{tabular}

Source: Field Survey, 2017

\subsubsection{Level of literacy}

Education is the key factor for the development of any country. It is now recognized that the problem of illiteracy in Bangladesh is embedded more among females than males. The government and various NGOs have been pursuing different programs to improve literacy rate in the country. National literacy rate ( 7 years and above) of total population is 66.67 percent (MoF, 2016). For the purpose of showing the level of literacy of the participating households, the literacy level was divided into five categories. Table 3 shows that there is no illiterate respondent because of the fact that at least able to sign one's name is a precondition to become member of SSS. The same table shows that persons able to sign their names were 64.44 percent of total in agriculture while it was 37.78 percent in petty business enterprise. The respective percentages of respondents having primary education were 17.78 and 35.55 percent during the study period. No person was found to have education above secondary level (Jalil, 2005). However, the respondents belonged to petty business enterprise had relatively higher literacy level.

Table 3. Literacy status of the respondents.

\begin{tabular}{lcccccc}
\hline Literacy status & \multicolumn{3}{c}{ Agriculture } & & Petty business & \multicolumn{2}{c}{ All } \\
\cline { 2 - 7 } & No. & Percent & No. & Percent & No. & Percent \\
\hline Able to sign only & 29 & 64.44 & 17 & 37.78 & 46 & 51.11 \\
Primary & 8 & 17.78 & 16 & 35.55 & 24 & 26.67 \\
Secondary & 8 & 17.78 & 12 & 26.67 & 20 & 22.22 \\
Above secondary & - & - & - & - & - & - \\
All & 45 & 100 & 45 & 100 & 90 & 100 \\
\hline
\end{tabular}

Source: Field Survey, 2017

While analyzing the literacy level of the family members ( 6 and above), it was observed that more or less equal proportion of the family members of both the groups were illiterate. The respondent households taking together who could able to sign only primary, secondary and above secondary levels of education were to the extent of $12.69,44.03,25$ and 6.71 percent respectively during the study (Table 4). Most of the respondent households irrespective of category attempted up to primary level (44.03 percent) in the villages (Rahman, 2009). 
Table 4. Educational level of the respondent household members.

\begin{tabular}{lcccccc}
\hline Literacy status & \multicolumn{3}{c}{ Agriculture } & & Petty business & \multicolumn{2}{c}{ All } \\
\hline & No. & Percent & No. & Percent & No. & Percent \\
\hline Illiterate & 16 & 11.43 & 15 & 11.72 & 31 & 11.57 \\
Able to sign only & 20 & 14.28 & 14 & 10.94 & 34 & 12.69 \\
Primary & 60 & 42.86 & 58 & 45.31 & 118 & 44.03 \\
Secondary & 32 & 22.86 & 35 & 27.34 & 67 & 25.00 \\
Above secondary & 12 & 8.57 & 6 & 4.69 & 18 & 6.71 \\
All & 140 & 100 & 128 & 100 & 268 & 100 \\
\hline
\end{tabular}

Source: Field Survey, 2017

\subsubsection{Occupational status of the respondents}

It is evident from Table 5 that the respondents appeared to be housewives to the extent of 60.00 and 42.22 percent for agriculture and petty business respectively. It is also observed from the same table that agricultural day laborers seems to be the main occupation of about 26.68 percent and petty business to be the secondary occupation of 53.34 percent . It is also observed that tailoring as main occupation was equally important to both groups (4.44 percent). So, it may be concluded that most of the respondents of the study area were housewives. In the case of subsidiary occupations, 75.00 and 83.90 percent of the respondents were found to serve as housewives respectively among agriculture and petty business enterprises.

Table 5. Occupational status of the respondents.

\begin{tabular}{lcccccccc}
\hline Occupation & \multicolumn{4}{c}{ Agriculture } & \multicolumn{3}{c}{ Petty business } \\
\cline { 2 - 9 } & No. & Main & & Subsidiary & Main & Subsidiary \\
\hline Housewife & 27 & 60.00 & No. & Percent & No. & Percent & No. & Percent \\
Agriculture day labor & 12 & 26.68 & 3 & 75 & 19 & 42.22 & 26 & 83.90 \\
Petty business & 2 & 4.44 & 2 & 8.50 & - & - & - & - \\
Tailoring & 2 & 4.44 & 1 & 4.17 & 24 & 53.34 & 5 & 16.11 \\
Service & 2 & 4.44 & - & - & - & 4.44 & - & - \\
Total & 45 & 100 & 24 & 100 & 45 & - & - & - \\
\hline
\end{tabular}

Source: Field Survey, 2017

\subsubsection{Average size of land holding of the respondent households}

In the present study, land use pattern as well as ownership was investigated into eight categories as shown in Table 6. The table reveals that average size of own land was 16.4 and 21.08 decimals and that of average cultivated land was 45.68 and 8.22 decimals for agriculture and petty business groups respectively (Madhura, 2007). It was evident from the table that the respondents did not have ponds either of own or leased in status.

Table 6. Average land holding of the respondents households (in decimal).

\begin{tabular}{llll}
\hline SI & Type of land & Agriculture & Petty business \\
\hline 1 & Own cultivated land & 7.02 & 6.09 \\
2 & Land rented out & - & 0.54 \\
3 & Land rented in & 37.02 & 2.13 \\
4 & Mortgaged in & 1.46 & 0.80 \\
5 & Mortgaged out & 0.40 & 1.69 \\
6 & Garden & & 11.96 \\
7 & Pond & 0.49 & 23.07 \\
8 & Homestead & 8.49 & 21.08 \\
9 & Total & 55.06 & 8.22 \\
10 & Average own land (legal status) (1+2+5+6+7+8) & 16.40 & \\
11 & Average cultivated land(defect to status) $(1+3+4)$ & 45.68 & \\
\hline
\end{tabular}

Source: Field Survey, 2017 
3.1.5. Average annual income of the respondent households

Income is the most important indicator of socio-economic status of people in rural as well as in urban environments. Table 7 indicates the annual income earned from different IGAs under the SSS micro credit program. For the respondent households of agriculture enterprise, average annual income was Tk 80726.57 while the same for petty business enterprise was Tk 74864.14 .

Table 7. Average Annual Income of the Respondent Households (Tk)

\begin{tabular}{llllllll}
\hline Sources & Agriculture & Petty business & Tailoring & Rickshaw/Van pulling & Service & Other & Total \\
\hline Agriculture & 55037.70 & 5288.88 & 6000 & 4000 & 6400 & 4000 & 80726.57 \\
& $(68.18)$ & $(6.54)$ & $(7.43)$ & $(4.95)$ & $(7.93)$ & $(4.95)$ & $(100)$ \\
Petty business & 11823.16 & 45733.33 & 3200 & 2888.88 & 5333.33 & 5884.44 & 74864.14 \\
& $(15.80)$ & $(61.08)$ & $(4.27)$ & $(3.86)$ & $(7.12)$ & $(7.87)$ & $(100)$ \\
All & 33530.43 & 25511.10 & 4600 & 3444.44 & 5866.66 & 4942.47 & 77795.35 \\
& $(42.96)$ & $(32.80)$ & $(5.91)$ & $(4.43)$ & $(7.55)$ & $(6.35)$ & $(100)$ \\
\hline
\end{tabular}

Source: Field Survey, 2017

Figures in the parentheses indicate percentages of total

\subsubsection{Average annual expenditure of the respondent households}

The average expenditure of a respondent household was incurred mainly for three purposes, i.e. agricultural expenditure meeting farm expenses comprising all sorts of expenses relating to production of agricultural commodities; expenditure for non-agricultural sector included the expenses relating to business, purchase of land, land mortgaged in, purchase of agricultural implements, purchase of live animal, etc. and family expenditure, only the expenses for buying commodities from the market in exchange of cash were taken into account in the present study. Expenditure for social ceremonies, house repairing, education, clothes, medical treatment, repayment of old debt etc. were also included in family expenditure. Table 8 shows that average annual expenditure of the respondents households. The average annual expenditure of the agriculture and petty business group was Tk 78776.65 and 67912.37, respectively.

Table 8. Average annual expenditure of the respondent households (Tk).

\begin{tabular}{lllll}
\hline \multirow{2}{*}{ Enterprise } & Expenditure & & \multicolumn{2}{c}{ Total } \\
\cline { 2 - 4 } & Agriculture & Non-agriculture & Family & \\
\hline Agriculture & 22679.76 & 2416 & 53680.89 & $(100)$ \\
& $(28.79)$ & $(3.07)$ & $(68.14)$ & 67912.37 \\
Petty business & 4729.26 & 10188 & 52995.11 & $(100)$ \\
& $(6.96)$ & $(15.01)$ & $(78.03)$ & 73344.51 \\
All & 13704.52 & 6302 & 53338 & $(100)$ \\
& $(18.69)$ & $(8.60)$ & $(72.72)$ & \\
\hline
\end{tabular}

Source: Field Survey, 2017

Figures in the parentheses indicate percentages of total

\subsubsection{Average annual savings of the respondent households}

Average annual savings of the respondent households were calculated by subtracting total expenses from corresponding total income during the study year. Table 9 indicates that the average annual savings of the respondent households are Tk 3733.25 and 8475.09. It express that petty business households saved more money to agriculture households in the study area.

Table 9. Average annual savings of the respondent households (Tk).

\begin{tabular}{llllll}
\hline Enterprise & $\begin{array}{l}\text { Average annual } \\
\text { income }\end{array}$ & $\begin{array}{l}\text { Average annual } \\
\text { expenditure }\end{array}$ & $\begin{array}{l}\text { Average annual } \\
\text { savings }\end{array}$ & $\begin{array}{l}\text { Compulsory } \\
\text { SSS society }\end{array}$ & $\begin{array}{l}\text { savings in } \\
\text { Total } \\
\text { savings }\end{array}$ \\
\hline Agriculture & 80726.57 & 78776.65 & 1949.92 & 1783.33 & 3733.25 \\
Petty business & 74864.14 & 67912.37 & 6951.76 & 1523.33 & 8475.09 \\
All & 77795.35 & 73344.51 & 5745.83 & 1653.33 & 7364.16 \\
\hline
\end{tabular}

Source: Field Survey, 2017

Figures in the parentheses indicate percentages of total 


\subsection{Adequacy, utilization and repayment of credit}

Adequacy, utilization and repayment of credit are very important factors for both lender and receiver of credit. Adequacy of credit shows the sufficiency of fund that makes the borrowers anxious free to invest it. Utilization indicates for what purposes the loaned money is used while repayment implies return of credit along with money to the lender within the specified credit period.

\subsubsection{Adequacy of credit}

Capital is required for investing in IGAs. To meet this capital requirement, credit is helpful as it creates scope for further investment. Findings regarding the adequacy of credit required by the women beneficiaries under study have been presented in Table 10.

Table 10. Receipt and adequacy of credit by the respondents.

\begin{tabular}{llll}
\hline Enterprise & $\begin{array}{l}\text { Average amount applied for } \\
\text { (Tk) }\end{array}$ & $\begin{array}{l}\text { Average amount received } \\
\text { for (Tk) }\end{array}$ & $\begin{array}{l}\text { Amount received as \% of } \\
\text { applied for }\end{array}$ \\
\hline Agriculture & 14933.333 & 11888.88 & 79.61 \\
Petty business & 12666.67 & 10155.56 & 80.17 \\
All & 13800.00 & 11022.22 & 79.89 \\
\hline
\end{tabular}

Source: Field Survey, 2017

Table 10 shows that the women in general revived almost 80 percent of average amount applied for all groups taken together. It also shows that agriculture enterprise group received more credit than that of petty business. So, as far as the adequacy of loan requirement of the women respondents are concerned, the amount received, however did not fully satisfy the loan requirement of the beneficiaries during the year of study.

\subsubsection{Utilization pattern of credit by respondent households}

Proper use of loan promotes increased production and benefits to the borrowers involved. In this chapter, an attempt has been made to see the pattern of loan utilization in which the sampled borrowers have spent their loan money received from SSS during the year under review. Table 11 shows the percentage distribution of total amount of loan spent for different purposes by the families surveyed. In the case of capital expenditure, the beneficiaries were found to have invested in four major capital items, namely, agricultural equipment, purchase of land, construction or repairing of house and purchase of the live animals. It is evident from the table that 52.50 and 30.41 percent of total loan was invested in capital items by agriculture and petty business enterprises respectively. Current expenditure indicates that 21.89 and 5.03 percent of total loan was used for various items of current expenditure by the enterprises respectively. The documented expenditures as considered in the present study were purchase of seed, purchase of fertilizer, purchase of insecticides, irrigation charge and charge for power tiller. Non-farm business expenditure is one of the main heads of expenditure especially for petty business category and the borrowers reported to have incurred 9.59 (agriculture) and 52.9 (petty business) percent of the total loan invested in business during the study period (Table 11). Family expenditure is one of the important heads of expenditure and the borrowers reported to have incurred 17.01 (agriculture) and 11.66 (petty business) percent of the total loan invested for various items of family affairs. Credit used by the respondents reveals that the beneficiaries at present are very much of positive attitude towards the proper loan use (SSS, 2016). From the table, it is evident that more than 80 percent of loan has been used for production purposes by the respondent groups in the study villages during the investigation. Loan use for family affairs was expectedly minimum the study area. 
Table 11. Utilization pattern of credit by the respondent households.

\begin{tabular}{lll}
\hline Items & Agriculture (Tk) & Petty business (Tk) \\
\hline Capital expenditure on farming & & \\
Purchase of land & $1600(13.46)$ & $355.55(3.50)$ \\
Purchase of agril. equipment & $1422.22(11.96)$ & - \\
Construction of house & $2355.55(19.81)$ & $1844.44(18.16)$ \\
Purchase of live animal & $864.46(7.72)$ & $88.88(8.75)$ \\
Sub-total & $6242.23(52.50)$ & $3088.88(30.41)$ \\
Current expenditure on farming & & \\
Purchase of seed or seedling & $888.89(7.47)$ & $200(1.97)$ \\
Purchase of fertilizer or manure & $1224.44(1.87)$ & $155.56(1.53)$ \\
Purchase of insecticides & $88.88(.75)$ & $44.44(.44)$ \\
Irrigation charge incurred & $222.22(1.87)$ & $66.67(.65)$ \\
Charge for power tiller & $177.78(1.50)$ & $66.67(.65)$ \\
Sub-total & $2602.21(21.89)$ & $511.11(5.03)$ \\
Non-farm business expenditure & & \\
Petty business & $666.67(5.60)$ & $2882.23(28.40)$ \\
Grocery shop & - & $2177.78(21.44)$ \\
Tailoring & - & - \\
Rickshaw /van purchase & $355.55(3.99)$ & $311.11(3.06)$ \\
Sub-total & & \\
Family expenditure & & $1184.44(11.66)$ \\
Total & $2022.22(17.01)$ & $10155.56(100)$ \\
\hline
\end{tabular}

Source: Field Survey, 2017

Figures in the parentheses indicate percentages of total

\subsubsection{Repayment of credit}

Repayment of credit is mostly related to its effective utilization. Use of credit for unproductive purposes very often results in overdue of loan and weakens the financial viability of the financial intuitions. The success of credit institution, therefore, depends mostly on the extent of proper utilization of credit supplied to the borrowers. The beneficiaries of SSS have to repay the loan through 45 installments. Findings related to the amount repaid with interest by respondents are presented in Table 12.

Table 12. Repayment of loan by respondent households.

\begin{tabular}{llllll}
\hline Enterprise & $\begin{array}{l}\text { Total installments } \\
\text { repaid }\end{array}$ & $\begin{array}{l}\text { Principal amount } \\
(\mathbf{T k})\end{array}$ & $\begin{array}{l}\text { Interest } \\
\mathbf{1 2 . 5 \%}\end{array}$ & $\begin{array}{l}\text { Total amount repaid } \\
(\mathbf{T k})\end{array}$ & $\begin{array}{l}\text { Percent of } \\
\text { repaid }\end{array}$ \\
\hline Agriculture & 45 & 11888.88 & 1486.11 & 13375 & 100 \\
Petty business & 45 & 10155.56 & 1269.44 & 11425 & 100 \\
All & 45 & 11022.22 & 1377.77 & 12400 & 100 \\
\hline
\end{tabular}

Source: Field Survey, 2017

Above table shows that the average amount of the loan received by agriculture and petty business enterprisers were found to be Tk. 11888.88 and 10155.56 respectively where 100 percent repayment of credit during the study period by the beneficiaries. So, credit repayment behavior of the beneficiaries was fully satisfactory during the year under study.

\subsection{Problems faced by the respondents to bring favorable changes}

Some questions were asked about the problems and constraints that hindered the respondents to bring expected and favorable changes by using SSS micro credit during the interview. The major problems and constraints have been presented in Table 13 . 
Table 13. Problems and constraints faced by the respondents.

\begin{tabular}{lllll}
\hline Problems and constraints & High & Moderate & Not at all & Total \\
\hline Lack of sufficient credit supply & 20 & 40 & 30 & 90 \\
& $(22.22)$ & $(44.45)$ & $(33.33)$ & $(100)$ \\
High interest rate & 33 & 30 & 27 & 90 \\
& $(36.67)$ & $(33.33)$ & $(30.00)$ & $(100)$ \\
Burden of old debt & 10 & 35 & 45 & 90 \\
& $(1.67)$ & $(48.49)$ & $(50.00)$ & $(100)$ \\
Lack of suitable marketing facilities & 40 & 50 & - & 90 \\
& $(44.44)$ & $(55.55)$ & & $(100)$ \\
Low price of different products & 35 & 55 & - & 90 \\
& $(38.88)$ & $(61.11)$ & & $(100)$ \\
Lack of storage facilities & 33 & 32 & 25 & 90 \\
Lack of improved seeds/breed & $(36.67)$ & $(35.55)$ & $(27.72)$ & $(100)$ \\
& 35 & 40 & 15 & 90 \\
Theft & $(38.88)$ & $(44.42)$ & $(16.37)$ & $(100)$ \\
& & 40 & 50 & 90 \\
\hline
\end{tabular}

Source: Field Survey, 2017

Figures within parentheses indicate percentages of total

From above table it is found that there are eight kinds of major problems which were opined by the respondents in the study area during the time of study. Here, the respondents expressed their problems in three degrees like 'high' 'moderate' and 'not at all' a problem. The answers given by the respondents against different problems were carefully handled and presented in percentage to be meaningful. The highest (66.67 percent) proportion of the respondents reported insufficiency of credit supply was a moderate problem and only 33.33 percent of them reported this not at all a problem to them. The interest rate charged by the SSS as a major problem, 36.67 percent of the respondents opined is as high. The respondents of the study area repaid their old debt which sometimes creates problems to utilize their credit for selected occupation. About 48.49 percent of the respondents reported that burden of old debt was not at all a problem while 1.67 percent said that it was a great problem to continue their existing activities (Bulbul, 2010). On the other hand, 36.67 percent of the beneficiaries reported lack of storage facilities as a great problem. Lack of improved seeds/breeds sometimes stands as problem to the women beneficiaries.

This faster progress of poverty reduction was made possible by the implementation of different programs at the government and non-government organizations level. SSS is one of the national NGOs working all over Bangladesh. SSS provides micro-credit to rural people of initiating and continuing their different IGAs. Many studies have been conducted on NGOs activities but there is want of comprehensive study on SSS micro credit program for rural women in the study area. Though such study on SSS is very much insufficient, but it is generally expected that SSS micro credit program has significant impact on poverty alleviation of rural women. This has inspired the researcher to conduct this study. The present study is concerned with the respondents who took loan from the SSS, Gouripur branch office in Mymensingh district. The study aims to examine the impact of SSS microcredit program, adequacy, and utilization of loan and repayment performance by the respondents.

\section{Conclusions}

The credit holders of SSS improved their livelihood as well as social status after involvement in SSS. Most of the credit was used for productive purposes by the beneficiaries. Loan repayment was quite satisfactory. Women participation in decision making of family affairs has been recognized by their male counterparts after joining the SSS group. The SSS micro credit program could have positively changed some of the socio-economic indicators of the beneficiaries. The study suggests for further study of similar type in other areas within the domain of SSS findings which would encourage the policy makers to formulate pragmatic program for rural development in the country in future.

\section{Conflict of interest}

None to declare. 


\section{References}

Alam ABMN, 2005. Rural Women in Micro-credit Programs of Poverty Alleviation: A study of BRAC in Sadar upazila of Netrokona district. M.S. Thesis, Department of Agricultural Finance, Bangladesh Agricultural University, Mymensingh.

ASB, 2016. National Encyclopedia of Bangladesh, Vol. 7, Asiatic Society of Bangladesh, Dhaka, Bangladesh

BBS, 2016. Statistical Year Book of Bangladesh, Ministry of Planning, Government of People's Republic of Bangladesh, Dhaka.

Bulbul T, 2010. A comparative economic Analysis on Microcredit Programs of Vegetables Cultivation and Beef Fattening of Jagorani Chakra Foundation (JCF) in Some Selected Areas of Jessore district. M.S. Thesis, Submitted to the Department of Agricultural Finance, Bangladesh Agricultural University, Mymensingh.

Jalil MA, 2005. Impact of Micro-credit Program of RDRS on Rural Women in Some Selected Areas of Kurigram district. M. S. Thesis, Submitted to the Department of Agricultural Finance, Bangladesh Agricultural University, Mymensingh.

Khatun MN, 2009. A Study on the Present Agricultural Credit Structure in Selected Areas of Kushtia district. M.S. Thesis, Submitted to the Department of Agricultural Finance, Bangladesh Agricultural University, Mymensingh.

Madhura S, 2007. The microcredit alternative? Economic and Political Weekly, 42: 1171-1175.

MoF, 2016. Bangladesh Economic Review, Economic Division, Ministry of Finance, Government of the People's Republic of Bangladesh, Dhaka, Bangladesh.

Rahman, 2009. The impact of RDRS micro credit program on rural livelihood and women empowerment in some selected areas of Rangpur district. M.S. Thesis, Department of Agricultural Economics, Bangladesh Agricultural University, Mymensingh.

SSS, 2016. Annual Report, 2015-16, Mymensingh, Society for Social Service.

UNFPA, 2016. State Of World Population, 2016, New York [online]. Available from: http://www.unfpa.org/swop. Accessed $2^{\text {nd }}$ December, 2016.

World Bank, 2016. World Bank Indicators 2016. Washington DC. World Bank. 